\title{
Global Financial Crisis of 2007: The Case of Albania
}

\author{
Ditmir Sufaj
}

Epoka University

\section{Doi:10.5901/mjss.2015.v6n4p130}

\begin{abstract}
The world financial crisis of 2007 had a severe impact on the global economy. The crisis started as a consequence of the nonwell performing banking system and led then not only to a financial crisis but also to a global economic crisis. Eight years after the outbreak of the financial crisis, it is still affecting the personal and public spending of many governments from all continents. Only the crisis of 1929-1933, known as Great Depression, can be compared to this crisis with regard to the damages it caused to the global economy. Since the effect of the crisis was spread all around the world, this means that all the countries have suffered from it, or at least they have had negative effects from it. Therefore, this study is particularly interested on a specific country, which is Albania. The study will provide the main developments that occurred in Albania during the crisis; how it was affected; how the government interfered to prevent it; how much serious was the damage caused by neighbor countries, especially Greece, since Greece was one of the countries that suffered the most from the crisis and there are many Albanian emigrants living in Greece. Given the consequences the crisis had in the world economy, it is expected that governments and international institutions will intervene to prevent such similar crisis, and therefore this study provides a discussion section in the last part.
\end{abstract}

Keywords: financial crisis, global economy, Albania, emigrants

\section{Introduction}

The global financial crisis of 2007 was introduced after a decade of economic stability, being caused mainly by the inefficient performance of the banking system and the financial sector. Economists argue that it is the worst financial and economic crisis since the crisis of 1930s. Generally speaking, the crises have originated from countries that have not good economic growth, but in this case the opposite happened; the crisis originated from the most advanced economies in the world, such as US and the EU countries. In this period, it was the first time that the developed countries started to use advanced financial methods; such as financial derivatives and other instruments that were traded globally. The effects of the crisis were very severe, causing many bankruptcies and failures of financial intermediary institutions. Further bank panics originated, since the banks lost their accountability and loyalty and therefore the customers would withdraw their savings from the banks. After all, the crisis is not over yet. Due to this fact all central banks and governments are taking measures of how they can bring back the financial stability and restore the confidence towards their customers. Additionally economists find it a challenge to explain these events of the crisis; how it is unfolding, and the actions needed to undertake for the resolution of the crisis. Due to the above mentioned reasons, it is important to take into consideration the Albanian case, since there were some mixed consequences of this crisis on its financial and economic sectors.

So, what will be explained through this paper are the main underlying reasons that this crisis occurred. Further this paper will give a review on the literature made by many scholars and professionals in the field of economics and finance. Next we are interested in knowing about the Albanian response and developments during the crisis. In studying the Albanian economy and its response there should be taken into consideration also the emigration factor and the economic conditions of the neighbor countries at which the Albanian citizens are working.

Actually Albania has previously undergone two major financial crises, including the pyramid crisis of 1997 and the crisis of 2002 and they were coming from inside the system. (Cani \& Haderi, 2002)(Cani \& Haderi, 2002). The last financial crisis doesn't come from inside the system; rather it is a transmission from the foreign countries and therefore we want to know the consequences it has presented in the Albanian economy (Bahiti \& Shkurti, 2011). Therefore the model is developed on the basis of emigration, the influence of their savings in the Albanian GDP, inflation and unemployment.

Further we want to know what measures and actions the government and the central bank should undertake in order to keep the banking system safe from such crisis, since it has the major weight in the Albanian financial system. 
These actions can be achieved by interacting efficiently both with the external and the internal environment.

\section{Overview of the Financial Crisis}

The world economic and financial crisis began by 2007 in USA, which was caused mainly from the liquidity problems in the banking system at the United States of America, where the fall in value of the real estate assets caused many damages to the financial institutions. Another related factor of the crisis origination was the uncovered collateral of mortgages, which therefore made bank consumers not pay back their credits, and therefore led to a bank panic.

The crisis was introduced mainly because of using advanced financial tools; consumers and even the bank employees were not trained to deal with these tools; and this had many consequences to the banking sector. After being initiated in USA, the crisis was fast spread in Europe and especially in EU zone, since the EU countries were trying to imitate the financial sector policies of USA, using financial derivatives ${ }^{1}$, mortgage loan facilities and such advanced financial tools. The consequences on EU zone were worse than in USA, because an event occurring in one country would affect the other countries within the EU zone immediately, since they have the same currency, the same monetary and trade policies with each other. There could be seen very bad effect on countries such as Greece (the Greek crisis affected mainly all the countries of Balkan), Italy, Spain, Portugal and Iceland. The main reason these countries were affected the most was because they were the last countries that entered in the EU, and therefore they had not a very sophisticated banking system and monetary policy (Diamond, 2008). The crisis on these countries affected all the EU member countries, since they had the same currency and the same trading rules. The crisis was soon transmitted to the economic sector. Since the major part of the economy of the countries was based in the financial intermediaries, there is no doubt that it would have a strong effect also in the economic sector.

At this point we'll have to take into consideration the so called business cycle. The economic crisis at the beginning was initialized by the increased unemployment, which was followed by a lower demand for goods and services, which led further to a decrease in output.

Taking into consideration the theoretical analysis it is observed that the causes and factors of the crisis have had the same trend. It soon became clear that the crisis was not to be attributed to the regulations of internal and foreign financial markets, but rather there was a mix of many factors, which consequently would result in lower investments, lack of liquidity and initiation of a debt. Since many factors were included in the origination of crisis, it became easier for it to be transmitted from the financial system to the real economy, therefore having consequences also in output (production), inflation and unemployment level. Regarding the geography also, the crisis started firstly in the developed countries and then spread in the developing or transition countries including all of the five continents.

\section{Literature Review}

Academicians use two different theories to explain the origination and the factors that caused the banking crisis. In the successful work of (Diamond, 2008), he arguments that panics are events caused by deposit withdrawals; indicating that these withdrawals are made in a random way and not according to the changes in the real economy. If depositors fear that other depositors will withdraw their money, then all customers find it appropriate to redeem their savings, leading to a bank panic.

The second theory that explains the origination of the financial crisis was introduced by (Hans Carlsson and Eric van Damme, 2009). These authors take into consideration the asymmetric information games, in which one of the parties has more information than the other one. According to their study this was one strong reason for the initiation of the crisis, since lenders (mainly banks) would have less information than borrowers, causing therefore adverse selection ${ }^{2}$ and moral hazard ${ }^{3}$ problems.

Based on the theoretical works of (Gorton, 1988) (Gorton, 1988), (Allen \& Gale, 2001) they introduced a model which is interrelated with the business cycle view regarding the origins of banking crises. The bank asset returns could be anticipated by using economic indicators. If the interest rates are high, then depositors will be willing to keep their money

\footnotetext{
${ }^{1}$ Financial derivatives are contracts that derive their value from the price of an underlying item, such as asset or index. They are contingency contracts that may or may not occur in the future, including forwards, futures, options and swaps.

${ }^{2}$ It is a subunit of asymmetric information before the credit is given. It includes the risk of providing the loan to the bad borrowers due to the lack of information. This leads to undesirable results.

${ }^{3}$ It occurs after the financial transaction has taken place. The borrower may use the money the bank lent to him, for other purposes than those stated in the contract. 
in the bank, while if the returns are expected to be low, they are not willing to keep their money in banks and consequently crisis occur.

Another author, (Tsoukalas, 2010) argued that there is a need for more sophisticated coordination of national economic policies, such as a combination of incentives and sanctions, integrated with effective surveillance and conditional assistance. However, these measures should not be taken at this moment, since this would make the general public blame the governments for the crisis. They should be undertaken after the crisis effects will disappear.

Many authors think that the main factors that contributed to the origination of the crisis were either inadequate regulatory system in US and EU markets (DeWind, 2007); or the low quality of the accounting and financial standard which were unable to verify the real risks coming from the crisis (Huian M. C., 2010).

The governing institutions were required also to undertake severe measures to handle the budget deficit problems. Most of the EU countries decreased the public expenses level and the level of taxes was either increased or new taxing system was presented in their respective fiscal systems (Dinger \& Von Hagen, 2009).

\section{Financial Crisis in Albania}

The Albanian financial system is quite new; it was developed mainly during nineteenth and twentieth century. Historically, it has been based mostly in the banking sector, more than in other sectors. The banking sector remains still the monopoly of providing financial services. This has brought a kind of systemic risk in the financial sector, since there is not much diversification of where individuals can invest their money and where others can take credits from.

Since the last crisis was a global one, it is obvious that, Albania also could not escape from the consequences of the crisis. When the crisis initially originated, Albania showed a kind of stability in regard to the problems and the pressure the world economy was facing (BoA, 2009). On the other hand, even though many countries undertook many aggressive measures to prevent and handle the crisis, the Albanian government took just a defending position. Albania was among very few countries in Europe that was continuing with a positive GDP growth during the initial stages of the crisis.

When the effects of the crisis were observed in Albania (starting from May 2008), the concentration of the crisis in the world was still remaining in the financial markets sector. Despite this, there were no severe effects in the Albanian economy until the end of 2008. The underlying reason for this is that Albania was yet in the initial stages of the advanced financial system; its integration and the level of sophistication into international financial markets was low, it had no concentration on interaction and trade with the foreign market and especially with the foreign financial intermediaries.

Another important reason why Albania was not affected by the crisis in its initial stages is attributed to the traditional business model, which has two mechanisms: (1) ensuring simple financing structure, where clients make deposits and banks use a very low leverage; and (2) offering basic products and services, different from crisis generating products such as derivatives. These basic products resulted as the most suitable and effective mechanism for the Albanian economic development. The main advantage of this model is that it was put under the control of the central bank of Albania and due to this fact it was strictly controlled. In the following paragraphs will be listed some other important reasons why Albania could escape the effects of the crisis in the initial years of its origination:

First of all, compared to the banking system of other developed countries, the Albanian banking system is relatively new. This indicates that like the economy of the country, which is in the developing stage, also the banking system is still in the growing stage, which explains that Albanian banks are not using many advanced and sophisticated financial procedures. Moreover the lack of a Stock Exchange is another indicator of why Albania was not much affected by the crisis.

Second, Central Bank of Albania monitors and regulates the secondary banks. By this procedure restrictions are imposed to these secondary banks with regard to the investment quality and quantity in the foreign markets. The portfolio of the assets has thus a higher quality and security by using this policy.

Third, Albanian banks don't need any external financing from the foreign market, since they have sufficient funding from the domestic market.

Fourth, the European Banks operating in Albania are not using the same policies as the US banks and the banks of EU countries with advanced financial procedures, and therefore this has created a soundness protection of the Albanian Banking system from the factors that created the crisis.

Finally, the Bank of Albania acts as a lender of last resort for investments that are denominated in domestic currency; while with regard to the foreign currency it has established regulations to hedge the liabilities denominated in other currencies. So, summarizing these factors we can conclude that the policies of BoA have resulted positive and successful until now (Shkurti, 2010).

Even though Albania was not affected initially by the global crisis, its effects were inevitable in the following years 
due to the trade and integration in the foreign international markets.

The crisis started to show its negative impact in the sectors of Albanian economy starting from 2009. The crisis consequences were mainly seen in worried public reactions, leading therefore to the withdrawal of deposits from the customers (mainly as a psychological effect). These negative effects were mainly transmitted from Greece, since it was one of the countries that suffered the most from the crisis and there were many Albanians living in Greece as emigrants.

The main concern was that this financial crisis would be transferred also to the economic sector of Albania. This came mainly from the loss of confidence in the banking sector, which made many depositors withdraw their money from banks. Despite this fact, there was no reason to do so, since Albania was not actually affected by the crisis by that time. The general public was afraid that the crisis would reach also to Albania since it had affected all the developed countries. The redemption of money from banks would cause the currency of the country to fall, since there was less money circulating in the market. Imports would become more expensive and Albanians could not afford these imports; exports decreased, since foreigners were not willing to buy Albanian goods; Emigrants would return back to their home country; level of FDI fell, since foreigners were afraid of investing in developing countries. All these factors combined together affected the Albanian economy and were a sign that Albanian economy could not escape from this globally oriented crisis.

\subsection{Effect of emigration for transmission of the crisis}

After the period of communism, Albanian people were massively migrating. Academicians suggest that Albania is one of the countries with largest number of migration in Europe in the last twenty years. Statistics show that one third of Albanian migrated abroad after 1990s. From these years and on, emigrants have provided much of the GDP growth in Albania, since they were returning the money they were profiting to their families living in Albania. So they have provided a kind of relief during difficult economic conditions, not only to their families but also to the Albanian state as a whole (Konica \& Filer, 2009).

The reason we are taking into consideration the role of emigrants in the crisis, is due to the fact that they were living in countries which were affected severely from the crisis. We could take here as an example Greece, which is the European country that had very severe effects by the crisis and there are around five hundred thousand Albanians living in Greece. So we are interested in here to know how these emigrants living abroad reacted to the crisis; whether they returned to the home country or not; what they did with their savings and so on.

The Greek crisis was established in 2008. As mentioned, above it is clear that this would have immediate impact also to Albanian migrants living there. The first action of Albanians living in Greece was withdrawing their money from Greek banks and transferring them to the banks of the home country. This trend continued from 2008 and it is still going on. Another issue is that many Albanian migrants would remain unemployed and therefore, they would consider returning to Albania. That's what happened in reality; around one sixth of Albanians living in Greece returned to Albania during the crisis period (Tsoukalas, 2010).

When the crisis started, Albania's GDP growth remained positive since emigrants were investing their remittances in Albanian banks and therefore this would increase the financial sector. Since the financial sector has the highest weight in Albanians GDP, this would lead to a GDP growth during the initial stages. On the other hand these migrants that returned back to their home country would open new small businesses, which in turn would generate more income and less unemployment.

(Konica \& Filer, 2009) have done a previous study on Albania to estimate the effects of remittances on unemployment level. This effect causes the increase of the labor supply of the households who have an emigrated member in their family, because they have to compensate the loss in their monthly incomes.

In the study of (Stahl \& Arnold, 1995), they argue that the use of remittances for consumption may have a positive effect on economic growth, since emigrants respond positively to the incentives of investment opportunities in their home country. Many emigrants invest their savings generally in small trading businesses in their home country because they have more information in the market of their own country rather than the markets of the host countries. We have to mention the importance and strong relationships in the Albanian families which are a vital factor and have a positive effect in the remittances level of the emigrants.

Even though at the beginning of the crisis, emigrants would return their savings back to the home country, these savings would be consumed during these times; indicating that remittances would fall in the following years and consequently the GDP of the country would fall. Since previously it was mentioned the weight of the remittances in the Albanian economy, it is clear that the decline in this variable would cause the GDP growth of the country to fall. Mainly these emigrants failed to succeed in the investments they undertook at their home country. 
Another negative factor to be mentioned during the crisis is that Albania started being affected by the crisis due to the reduction of trade with these countries that were affected by the crisis, such as Greece and Italy.

\section{Data, Methodology and Analysis}

\subsection{Data and Methodology}

In the previous sections was explained theoretically what happened during the crisis in the world and in Albania as a special case. Theoretical statements are generally forgotten fast, so if there is statistical proof related to the topic, the reader will find it hard to understand what the paper is talking about. Due to this fact, in this section we will provide some data and visual graphs of the effect of the crisis in Albania, since it is the special case taken into consideration in the study. The components which we are interested at are GDP growth rate, unemployment rate, inflation rate and remittances return to the country; all these data are taken into consideration during the crisis time interval.

From the econometric point of view, it is known that to construct a regression there should be a long time interval (more than 50 observations available). Instead, we can provide data only for up to 10 years, so this is not enough to construct a regression. Consequently, we are not able to construct a regression in the methodology part. So the way our study is going to proceed is by constructing graphs of how these components have moved during the years; we can therefore compare the effect of falling remittances in the GDP growth or in the unemployment rate; we can further compare the Albanian GDP growth to that of the neighbor countries etc.

\subsection{Analysis}

Given the data provided by Bank of Albania, World Bank and World Trading Economies, we have seen the behavior of some of the main variables in the Albanian economy, such as GDP growth rate, unemployment rate, inflation rate and remittances return as percentage of GDP. These are the main indicators of how an economy is performing, and that is the main reason why we are taking into consideration these components. One should expect that if the level of remittances falls, this will cause the GDP growth rate to decline; which further by the business cycle theory leads to an increase in unemployment rate and an increase in inflation (Gorton, 1988)(Gorton, 1988). This is only the theoretical assumption; so we want to see what really happened with the real data. In the following graph are shown the trends of these components (refer to Appendix part for the source of data) from 2005 (two years before the crisis) to 2014 (which is seven years after the crisis started and that is still going on in most of the countries).:

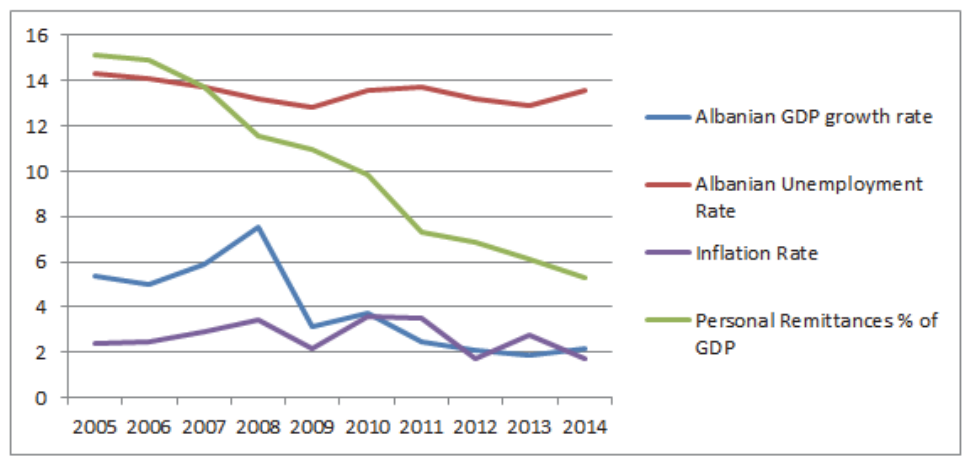

Figure 1: Movement of GDP, Inflation, Unemployment and Remittances during the crisis years

First of all, it should be taken into consideration the movement of personal remittances across the time, since it is a component that would cause the main indicators of the economic growth to perform badly. As it was stated also in the other sections, Albanians rely too much on emigration and the level of remittances that they are receiving from these emigrants; indicating that if this factor would decline, it would cause also the other components to decline.

As it can be seen from the graph the, from 2005 and on, level of personal remittances received has been declining, which therefore would affect also the GDP growth rate also in a negative way. As it was stated before that Albania was not directly affected by the crisis, it can be proved now by the GDP growth rate, which until the midyear of 2008 was increasing steadily. In the years of 2009 and 2011 the GPD growth rate had a sharp decline, due to the crisis affect. After 
these years it has remained mainly stable and it is important to mention that it has not reached the negative zone (it is still above zero). The effect of the crisis on inflation rate was not very significant; it was mainly seen in 2009 when the inflation had not very significant increase. Through the other years it has mainly remained stable. Inflation remained stable mainly because of the strict monetary policies of Bank of Albania. So, this variable was expected to increase, but because of the role of BoA it could remain stable. Since GDP fell, it is expected that unemployment would also fall; still this was not the case in our study. Since there were many emigrants coming back to Albania, they would open new small businesses, hire employees and this was one of the main reasons why unemployment also had not been much affected by the crisis. As a conclusion we can say that generally during a crisis, one should expect the GPD to fall, unemployment to rise and inflation to rise. In the Albanian case, this rule was not much valid, since there are many other external factors affecting its economy, such as remittances, role of BoA, traditional way of operating the financial intermediaries etc... and due to these factors the Albanian economy was not much affected by the crisis.

\section{Discussion}

The economic crisis is still going on nowadays and it's mainly affecting the personal income of the individuals, especially of those who have low-income levels. Governments should take several actions in order to help these people pass this critical moment. The government should focus its investments in the public services, by building new national roads, railways, new schools and also new healthcare systems.

Since the crisis happened for not paying attention to the financial sector and the way it is proceeding, nowadays and on it is important to monitor this sector and especially banks. This monitoring process should be organized by politicians and followed carefully by experts. (Huian M. C., 2010).

There is high risk that the economic crisis could bring a food crisis. To prevent this, governments worldwide should take some precautions, such as putting off export barriers with their neighbors, assuring sustainable financing for the local agencies that deliver food and also they should improve the coordination with other countries in getting the right information anytime, anywhere about the global food reserves. Also important in these cases is the investment in agriculture and in rural zones, so that if any crisis happens again people won't suffer for food.

From the findings of (Fullani, 2008), he argued that one of the reasons that Albania didn't suffer immediately from the crisis is because of a strong fiscal policy which enabled to keep the budget deficit at adequate levels. This control of the public spending has allowed the government to control the internal demand and to increase the confidence with regard to the macroeconomic stability.

He further concluded that controlling the financial stability is one of the most important components in assessing the long-term economic development, and that this stability could be achieved by increasing the confidence level in the banking system. For a country to leave behind the transition and the crisis period it is important to have an interaction between the banking sector and the real economy in terms of savings, development, expertise and financial support.

Some of the recommendations needed to be applied in the future are listed below:

- The reduction of the political influence on the economical decisions.

- The systematic development of the agricultural and energy sector.

- The promotion within the public administration of the best international practices.

- Investments at the research areas and to the information technology.

\section{Conclusions}

In this study was analyzed one of the most severe and complex global financial crisis in recent times. The main factors that contributed to the introduction of the crisis were mortgage loans in US, uncontrolled collateral, advanced financial instruments (financial derivatives), lack of supervision and most importantly the increased globalization of economy, which would make it easier to transmit the crisis from one region to another. These factors were studied in detail in previous sections and the underlying reasons that they contributed to the crisis. From the previous research it was concluded that the primary factor was the lack of supervision from public authorities, which enabled bank authorities to provide loans in an uncontrolled way. It was argued that the authorities should have a more sophisticated and coordinated supervision in the future at a global level, since we are moving towards a global economy. With this way it is possible to achieve a financial stability and a well-performing of financial systems.

It was mentioned also, that the crisis originated in developed countries, since they were the ones using more the advanced financial tools. Due to this reason, the financial markets of emerging countries were not much affected by the crisis, at least initially, since they were not using any complex financial tool; indicating that they were oriented towards the 
traditional banking. Similarly, Albania was not directly affected by the financial crisis; the consequences could only be observed after the crisis affected the real economy of the developed countries. Since Albania is a country which is based too much in exports, and trading would become more expensive, this would have a negative effect in the Albanian economy, but not too much in the financial system. Looking at this crisis as a lesson for all countries; and especially for Albania, it is important that the BoA monitors, strengthens and takes new measures to keep the financial stability. Moreover it is important to have a daily monitoring of the new international regulations and procedures in the financial and economic sector.

Lastly another important component for avoiding such crisis is that government should support and finance for professional discussions in the related topics by academicians and experts. This would provide a better understanding of the situation by the general public would serve as an advisory component for secondary banks and would further avoid such severe crisis in the future.

\section{References}

Albanian Foreign Trade Report (2011) Tirana: ACIT (Albanian Centre for Competitiveness and International Trade)

F. Allen, \& D. Gale (2001) , Comparative Financial Systems; A survey (pp. 23-41). New York: The MIT Press.

Bahiti, R., \& Shkurti, R. (2011). Impact of the Latest Financial Crisis on Bank Based Financial System; Albanian Case. The Romanian Economic Journal , 3-23.

Bank of Albania. (n.d.). Retrieved December 11, 2014, from http://www.bankofalbania.org/

BoA. (2009). Annual Report. Tirana.

Cani, S., \& Haderi, S. (2002). Albanian Financial System in Transition; Progress or Fragility. Third National Conference; Bank of Albania in the second transition decade. Tirana: Bank of Albania.

DeWind, J. a. (2007). Fourth Coordination Meeting. Internal and international migration in economic development on International Migration, Population Division, Department of Economic and Social Affairs, United Nations , pp. 50-62.

Diamond. (2008). Baseline findings from the Diagnosis, Management and Outcomes of Depression in Primary Care Longitudinal Study. Depression and Primary Care, 119-125.

Dinger, V., \& Von Hagen, J. (2009). How small are the Banking Sectors in Central and Eastern European countries really. Journal of Financial Regulation and Compliance, 96-118.

(2010). Financial Stability Report. Tirana: Bank of Albania.

Fullani, A. (2008). Recent economic and financial developments in Albania. Monetary Policy Statement (pp. 1-4). Tirana: Bank of Albania.

Gorton, G. (1988). Banking Panics and Business Cycles. Oxford Economic Journal , 751-781.

Hans Carlsson and Eric van Damme. (1993). Global Games and Equilibrium Selection. Econometria, 989-1018.

Huian, M. C. (2010). Impact of current financial crisis on disclosures. Analele Stiintifice Ale Universitatii "Alexandru loan Cuza" Din lasi , 41-49.

Huian, M. (2010). Instruments of Financial Accounting. IFR Journal , 11-30.

IBM. (2010, October). Global Financial Stability Report .

Jaganathan, V., \& Chari, R. (1988). Banking Panics, Information and Rational Expectations Equilibrium. The Journal of Finance, 749761.

Konica, N., \& Filer, R. (2009). Albanian Emigration; Causes and Consequences. South-Eastern Europe Journal of Economics 1, 76-98.

Albanian Foreign Trade Report (2011) Tirana: ACIT (Albanian Centre for Competitiveness and International Trade)

F. Allen, \& D. Gale (2001), Comparative Financial Systems; A survey (pp. 23-41). New York: The MIT Press.

Bahiti, R., \& Shkurti, R. (2011). Impact of the Latest Financial Crisis on Bank Based Financial System; Albanian Case. The Romanian Economic Journal , 3-23.

Bank of Albania. (n.d.). Retrieved December 11, 2014, from http://www.bankofalbania.org/

BoA. (2009). Annual Report. Tirana.

Cani, S., \& Haderi, S. (2002). Albanian Financial System in Transition; Progress or Fragility. Third National Conference; Bank of Albania in the second transition decade. Tirana: Bank of Albania.

DeWind, J. a. (2007). Fourth Coordination Meeting. Internal and international migration in economic development on International Migration, Population Division, Department of Economic and Social Affairs, United Nations , pp. 50-62.

Diamond. (2008). Baseline findings from the Diagnosis, Management and Outcomes of Depression in Primary Care Longitudinal Study. Depression and Primary Care , 119-125.

Dinger, V., \& Von Hagen, J. (2009). How small are the Banking Sectors in Central and Eastern European countries really. Journal of Financial Regulation and Compliance, 96-118.

(2010). Financial Stability Report. Tirana: Bank of Albania.

Fullani, A. (2008). Recent economic and financial developments in Albania. Monetary Policy Statement (pp. 1-4). Tirana: Bank of Albania.

Gorton, G. (1988). Banking Panics and Business Cycles. Oxford Economic Journal , 751-781.

Hans Carlsson and Eric van Damme. (1993). Global Games and Equilibrium Selection. Econometria, 989-1018. 
Huian, M. C. (2010). Impact of current financial crisis on disclosures. Analele Stiintifice Ale Universitatii "Alexandru loan Cuza" Din lasi , 41-49.

Huian, M. (2010). Instruments of Financial Accounting. IFR Journal , 11-30.

IBM. (2010, October). Global Financial Stability Report .

Jaganathan, V., \& Chari, R. (1988). Banking Panics, Information and Rational Expectations Equilibrium. The Journal of Finance , 749 761.

Konica, N., \& Filer, R. (2009). Albanian Emigration; Causes and Consequences. South-Eastern Europe Journal of Economics 1, 76-98.

Nistor, I., \& Ulici, M. (2009). Impact of financial crisis over the evolution of banks from the capital market, Finance - Challenges of the Future. University of Craiova, Faculty of Economics and Business Administration (pp. 22-31). Science Direct.

Remittances: Albanian experience. (n.d.). Retrieved December 07, 2014, from Bank of Albania: http://www.imf.org/external/np/sta/bop/ 2006/luxgrp/pdf/albani.pdf

Shkurti, R. D. (2010). The assessment of the financial soundness of the banking sectors in Balkan countries using "early warning indicators" - a comparative study with policy implications". CEA Journal of Economics , 33-48.

(November 15th 2011). South East Europe Regular Economic Report. World Bank.

Stahl, \& Arnold. (1995). Remittances From International Emigration. The Review of Economics and Statistics, 137-146.

The World Bank. (n.d.). Retrieved December 13, 2014, from http://www.worldbank.org/

Trading Economies. (n.d.). Retrieved December 5, 2014, from http://www.tradingeconomics.com/

Transition report 2011. Crisis in transition: the people's perspective. (2011). European Bank for Reconstruction and Development. London: EBRD.

Tsoukalas, J. D. (2010). The Greek Debt Crisis: Likely Causes, Mechanics and Outcomes. Cardiff Economics Working Papers , 1-32.

\section{Appendixes}

Table 1: Movements along time in GDP, Inflation, Unemployment and Personal Remittances

\begin{tabular}{lcccccccccc} 
Variable/Year & 2005 & 2006 & 2007 & 2008 & 2009 & 2010 & 2011 & 2012 & 2013 & 2014 \\
\hline Albanian GDP Growth (\%) & 5.4 & 5 & 5.9 & 7.5 & 3.1 & 3.7 & 2.5 & 2.1 & 1.9 & 2.2 \\
\hline Albania Unemployment Rate & 14.3 & 14.1 & 13.7 & 13.2 & 12.8 & 13.6 & 13.7 & 13.2 & 12.9 & 13.6 \\
\hline Personal Remittance \% of GDP & 15.12 & 14.9 & 13.71 & 11.53 & 10.94 & 9.81 & 7.3 & 6.89 & 6.15 & 5.31 \\
\hline Inflation Rate & 2.4 & 2.5 & 2.9 & 3.4 & 2.2 & 3.6 & 3.5 & 1.7 & 2.8 & 1.7
\end{tabular}

Sources: Data were collected from Bank of Albania, World Bank and Trading Economies 